\title{
希土類永久磁石のための新しい粉体粉末治金技術
}

\author{
高木 健太*, 平山 悠介, 岡田 周祐, 山口 渡, 尾崎 公洋 \\ （国研）産業技術総合研究所磁性粉末冶金研究センター， ４ 463-8560 名古屋市守山区下志段味字穴ヶ洞 2266-98.
}

\section{Novel Powder Processing Technologies for Production of Rare-earth Permanent Magnets}

\author{
Kenta TAKAGI*, Yusuke HIRAYAMA, Shusuke OKADA, Wataru YAMAGUCHI and Kimihiro OZAKI \\ Magnetic Powder Metallurgy Research Center, National Institute of Advanced Industrial Science and Technology (AIST), \\ 2266-98 Anagahora, Shimo-Shidami, Moriyama-ku, Nagoya 463-8560, Japan.
}

Received March 29, 2021; Revised May 6, 2021; Accepted May 7, 2021

\begin{abstract}
Post-neodymium magnets that possess high heat resistance, coercivity, and $(B H)_{\max }$ are desired for futuregeneration motors. However, the candidate materials for post-neodymium magnets such as $\mathrm{Sm}_{2} \mathrm{Fe}_{17} \mathrm{~N}_{3}$ and metastable magnetic alloys have certain process-related problems: low sinterability due to thermal decomposition at elevated temperatures, deterioration of coercivity during sintering, and the poor coercivity of the raw powder. Various developments in powder processing are underway with the aim of overcoming these problems. So far, the development of advanced powder metallurgy techniques has achieved $\mathrm{Sm}_{2} \mathrm{Fe}_{17} \mathrm{~N}_{3}$ anisotropic sintered magnets without coercivity deterioration, and advances in chemical powder synthesis techniques have been successful in producing $\mathrm{Sm}_{2} \mathrm{Fe}_{17} \mathrm{~N}_{3}$ fine powders with huge coercivity. The challenge of a new powder process is expected to open the way to realizing post-neodymium magnets.
\end{abstract}

\section{KEY WORDS}

rare-earth permanent magnets, sintering, powder synthesis, coercivity, $\mathrm{Sm}_{2} \mathrm{Fe}_{17} \mathrm{~N}_{3}$

\section{1 緒 言}

現代社会には不可欠となったハイブリット自動車やエコ家 電は, 飛躍的な高効率化を実現した埋込磁石型同期モーター (IPMSM) の登場によって生み出された。このモーターの性 能は永久磁石の性能に依るところが大きく, 次世代モーター に向けては更に高性能な磁石の登場が求められている. 加え て, 現行のネオジム磁石には常に資源問題が付きまとう ${ }^{1,2}$. $\mathrm{Nd}_{2} \mathrm{Fe}_{14} \mathrm{~B}$ 磁石の耐熱性を向上させるために必要な添加物であ る $\mathrm{Dy}$ や $\mathrm{Tb}$ 元素は地殼存在率が低いうえに産出地の地域偏 在性が強いため, 価格が国際情勢に影響されやすい. 以上の ことから, 現状を超える磁石性能をもち, かつ原料調達の安 定化ができるポスト $\mathrm{Nd}_{2} \mathrm{Fe}_{14} \mathrm{~B}$ 磁石の開発が望まれている.

Fig. 1 は各磁性化合物の永久磁石として潜在力を, 飽和磁 化 $J_{s}$ と異方性磁界 $H_{a}$ を指標として比較した． 飽和磁化と異 方性磁界が高い化合物ほど高い残留磁化と保磁力をもつ高性

* Corresponding author, E-mail: k-takagi@aist.go.jp

本論文のオリジナルの論文は “Science and Technology of Advanced Materials (STAM)”Vol. 22, No. 1, pp. 150-159 に掲載済みである.
能な磁石が期待できる。 また，モーター設計には磁石から取 り出すことのできる最大エネルギーである $(B H)_{\max }$ が重要な ため, その理論值 $\left(=J_{s}^{2} / 4 \mu_{0}\right)$ を Fig. 1 の横軸として併用した. 現在までに $\mathrm{Nd}_{2} \mathrm{Fe}_{14} \mathrm{~B}$ 磁石と同等以上の残留磁化および異方 性磁界を持つ化合物は $\mathrm{Sm}_{2} \mathrm{Fe}_{17} \mathrm{~N}_{3}$ や $\mathrm{TbCu}_{7}$ 型希土類遷移金属 化合物（例えば $\left.(\mathrm{SmZr})(\mathrm{FeCo})_{10} \mathrm{~N}_{\mathrm{x}}\right), \mathrm{ThMn}_{12}$ 型希土類遷移金 属化合物（例えば $\mathrm{Sm}(\mathrm{FeCo})_{12}$ や $\mathrm{NdFe}_{12} \mathrm{~N}_{\mathrm{x}}$ ）の 3 種類しか見出 されていない ${ }^{3-8)}$. 例えば, $\mathrm{Sm}_{2} \mathrm{Fe}_{17} \mathrm{~N}_{3}$ は 1990 年に Iriyamaや Coeyらにより初めて報告された磁性化合物であり，その飽 和磁化は $\mathrm{Nd}_{2} \mathrm{Fe}_{14} \mathrm{~B}$ と同等ながら, 異方性磁界は約 3 倍とな る $20.7 \mathrm{MA} / \mathrm{m}$ を示す ${ }^{3,4)}$. 最近のモーターには大きな保磁力が 要求されることから, この巨大異方性磁界は大変魅力的で

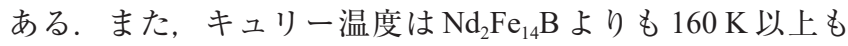
高く，優れた耐熱性も期待できる．一方で，他の 2 種類の候 補化合物については Fig. 1 から分かるように, さらに高い飽 和磁化を有する. Fig. 2 は上記の 3 つの化合物の理論 $(B H)_{\max }$ の温度依存性を文献值から予測した図である。ここで，理 論 $(B H)_{\text {max }}$ は $B_{r}=0.8 J_{s}$ と仮定して計算している. 図から分 


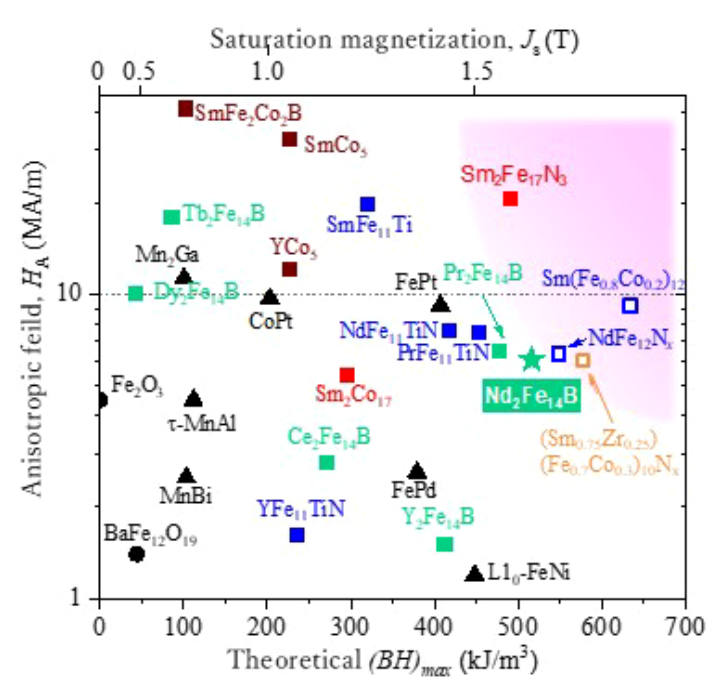

Fig. 1 Comparison of magnetic properties of various magnetic compounds. The rectangle, triangle, and circle symbols represent rare-earth alloys, non-rare-earth alloys, and oxides. The same color (except black) means the same crystal structure. Open symbols represent a compound for which a single crystal powder has never been obtained $^{56)}$.

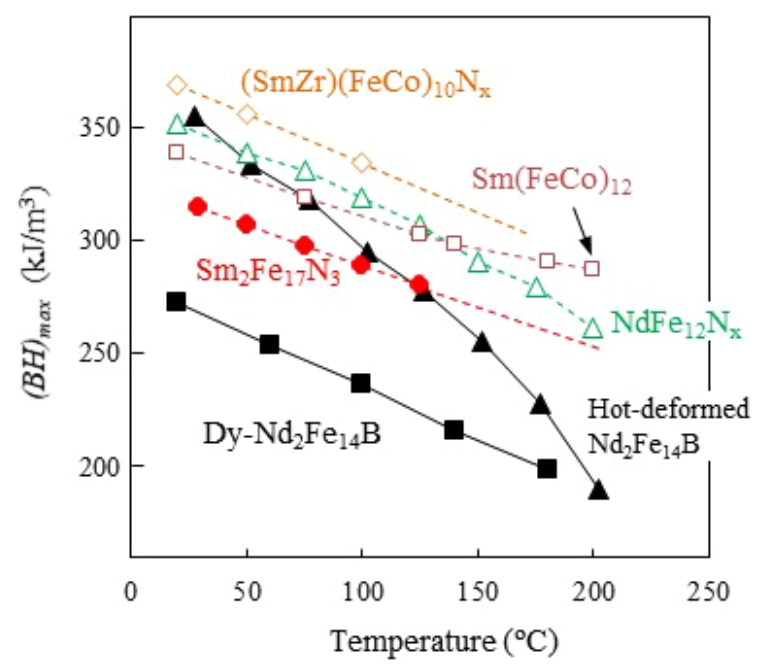

Fig. 2 Comparison of temperature dependencies of $(B H)_{\max }$. The values of Dy-added and hot-deformed $\mathrm{Nd}_{2} \mathrm{Fe}_{14} \mathrm{~B}$ sintered magnets are experimental ${ }^{9,10)}$. The $(B H)_{\max }$ of the other materials are theoretical values that are calculated with $0.8 J_{s}^{5,7,8,45,57-59)}$.

かるように, $\mathrm{Sm}_{2} \mathrm{Fe}_{17} \mathrm{~N}_{3}$ は $120^{\circ} \mathrm{C}$ 以上では最新の熱間強加工 $\mathrm{Nd}_{2} \mathrm{Fe}_{14} \mathrm{~B}$ 磁石よりも高い $(B H)_{\text {max }}$ が期待できる. またこの化 合物は，既存技術によって異方性磁石の作製に必要な単結晶 粉末の生産が容易である. 加えて, Sm 元素は北米や豪州な ど広域に埋蔵しており，かつ他の工業用途が少ないことから $\mathrm{Nd}_{2} \mathrm{Fe}_{14} \mathrm{~B}$ 磁石に比べて資源的課題は遥かに小さい.さらに, $\mathrm{TbCu}_{7}$ 型や $\mathrm{ThMn}_{12}$ 型の化合物は, さらに高い飽和磁化と耐 熱性を有することが見出されており，Fig. 2 に示すように高 温域では $\mathrm{Sm}_{2} \mathrm{Fe}_{17} \mathrm{~N}_{3}$ を超える性能が期待できる.

しかしながら，これらの候補化合物を実用的なバルク磁石 するには3つの大きな課題を有している. 一般的に, 希土類 化合物の焼結磁石は, 単結晶粉末の製造工程一磁場配向成形
工程－焼結工程を経て作製される，一つ目の課題は，粉末の 性能を保ったまま焼結することが難しことにある. $\mathrm{Nd}_{2} \mathrm{Fe}_{14} \mathrm{~B}$ の場合, 液相焼結が適用できるために保磁力向上や緻密化が 得られることは良く知られている。しかし, 候補材料のうち $\mathrm{Sm}_{2} \mathrm{Fe}_{17} \mathrm{~N}_{3}$ や $(\mathrm{SmZr})(\mathrm{FeCo})_{10} \mathrm{~N}_{\mathrm{x}}$ などの窒化物は熱分解性のた め, 5,10), $\mathrm{Nd}_{2} \mathrm{Fe}_{14} \mathrm{~B}$ のように高温まで加熱する液相焼結は難し い. したがって，低温加熱により焼結せざるを得ないため, 液相焼結による粉末表面の清浄化や緻密化の効果は期待でき ず，焼結磁石の磁石性能は粉末から大幅に劣化する。二つ目 の課題は，高い異方性磁界を有するにも関わらず，それに見 合う保磁力が得られないことである。 上述の通り, $\mathrm{Nd}_{2} \mathrm{Fe}_{14} \mathrm{~B}$ 磁石では液相焼結によって粉末表面が清浄化される結果と して, 異方性磁界の $30 \%$ 以上の保磁力が得られてる. 一方 で, 例えば $\mathrm{Sm}_{2} \mathrm{Fe}_{17} \mathrm{~N}_{3}$ では, 粉末状態において異方性磁界の $7 \%$ 程度の保磁力しか得られていない ${ }^{11)}$. 三つ目の課題は, $\mathrm{TnCu}_{7}$ 型や $\mathrm{ThMn}_{12}$ 型の化合物は準安定相であるため, これ までは急冷法や HDDR 法などで粉末を合成するしかなく， 結果として異方性磁石の原料としては利用できない多結晶粉 末しか得られていない ${ }^{12-16)}$

$\mathrm{Sm}_{2} \mathrm{Fe}_{17} \mathrm{~N}_{3}$ をはじめとする候補化合物の潜在力を引き出し, $\mathrm{Nd}_{2} \mathrm{Fe}_{14} \mathrm{~B}$ を超える磁石とするには, $\mathrm{Nd}_{2} \mathrm{Fe}_{14} \mathrm{~B}$ にはない上記の 問題を克服する必要がある．特に，これらの問題は粉末作製 や粉末固化の工程が強く関与していることから，工程中で起 こる現象を分析し，その科学的根拠に基づいた新たな粉末治 金技術の開発が行われている。そこで，本稿ではこれらの問 題の解決に向けたこれまでの研究成果を固化成形技術と粉末 作製技術の観点から紹介する. 特に, $\mathrm{Sm}_{2} \mathrm{Fe}_{17} \mathrm{~N}_{3}$ は候補化合 物の中で最もよく知られ, かつ一部実用化もされていること から, 紹介内容は $\mathrm{Sm}_{2} \mathrm{Fe}_{17} \mathrm{~N}_{3}$ の研究を中心とする.

\section{2 焼結・固化成形技術}

\section{1 熱分解型希土類磁石の粉末固化成形技術}

$\mathrm{Sm}_{2} \mathrm{Fe}_{17} \mathrm{~N}_{3}$ や $(\mathrm{SmZr})(\mathrm{FeCo})_{10} \mathrm{~N}_{\mathrm{x}}$ などの窒化物磁石の熱分解 温度は $600^{\circ} \mathrm{C}$ 付近であり, それ以上に加熱すると磁石特性 を失う ${ }^{5,9,10)}$. これらの熱分解温度は $\mathrm{Sm}-\mathrm{Fe}$ 系の液相出現温度 $\left(720^{\circ} \mathrm{C}\right)$ より低いため, $\mathrm{Nd}_{2} \mathrm{Fe}_{14} \mathrm{~B}$ のように液相焼結によって 容易に緻密化することはできない，そこで，熱分解以下での 緻密化のため $\mathrm{Sm}_{2} \mathrm{Fe}_{17} \mathrm{~N}_{3}$ の研究初期には, Table 1 に示すよう に低温加熱でも緻密化が可能なホットプレスや熱間等方圧プ レスなどの加圧焼結法が試みられてきた ${ }^{17,18)}$. その後, さら なる熱負荷を減らす目的として, 放電プラズマ焼結や通電焼 結などの高速加圧焼結も適用された ${ }^{19,20)}$. いずれも, 熱分解 なく焼結固化はできるものの, 保磁力の大幅な減少という問 題が立ちはだかった．例えば放電プラズマ焼結や熱間等方圧 プレスの場合には, 保磁力 $600 \mathrm{kA} / \mathrm{m}$ 以上の $\mathrm{Sm}_{2} \mathrm{Fe}_{17} \mathrm{~N}_{3}$ 粉末を 熱分解温度より $100^{\circ} \mathrm{C}$ 以上低い温度で燒結しても, 保磁力は $300 \mathrm{kA} / \mathrm{m}$ まで低下する ${ }^{19)}$. その他の方法を含めても, 保磁力 は焼結によって 35 75\% 低下する。 そして，この現象は従来 は熱分解の一種と考えられ，保磁力低下は不可避とされた． そこで, 衝撃成形法や微粉末噴射法, 圧縮せん断法などの常 
Table 1 Properties of $\mathrm{Sm}_{2} \mathrm{Fe}_{17} \mathrm{~N}_{3}$ magnets consolidated by various methods. $T_{c o n s}, H_{c j}$, and $\rho$ represent the consolidation temperature, coercivity, and density, respectively.

\begin{tabular}{|c|c|c|c|c|c|c|}
\hline \multirow{2}{*}{ Consolidation method } & \multirow{2}{*}{$\begin{array}{l}T_{\text {cons. }} \\
\left({ }^{\circ} \mathrm{C}\right)\end{array}$} & \multicolumn{2}{|c|}{$H_{c j}(\mathrm{kA} / \mathrm{m})$} & \multirow{2}{*}{$\rho(\%)$} & \multirow{2}{*}{$\begin{array}{l}(B H)_{\max } \\
\left(\mathrm{kJ} / \mathrm{m}^{3}\right)\end{array}$} & \multirow{2}{*}{ Ref. } \\
\hline & & powder & bulk & & & \\
\hline \multicolumn{7}{|l|}{ Sintering processes } \\
\hline Ultra high-pressure sintering & 550 & 700 & 453 & 97 & 88 & [17] \\
\hline Hot isostatic pressing & 450 & 600 & 300 & 90 & 118 & [18] \\
\hline \multirow{2}{*}{ Spark plasma sintering } & 500 & $\approx 680$ & $\approx 310$ & 89 & - & [19] \\
\hline & 420 & $\approx 850$ & $\approx 200$ & 85 & 50 & {$[28]$} \\
\hline Current sintering & 450 & 1162 & 287 & 82 & - & {$[20]$} \\
\hline \multirow{2}{*}{ Low-oxygen process } & 420 & 720 & 730 & 85 & 167 & [28] \\
\hline & 500 & 987 & 870 & 91 & 191 & [29] \\
\hline \multicolumn{7}{|l|}{ Cold compaction processes } \\
\hline \multirow{4}{*}{ Shock/explosion compaction } & - & 700 & 34 & 77 & 88 & [21] \\
\hline & - & - & 400 & 97 & 84 & [22] \\
\hline & - & 358 & 454 & 98 & 174 & [23] \\
\hline & - & - & - & $\approx 100$ & 191 & {$[24]$} \\
\hline Aerosol deposition & - & 923 & 1480 & 77 & - & [25] \\
\hline \multirow{2}{*}{ Compression shearing } & - & 860 & 920 & 84 & - & [26] \\
\hline & - & - & 880 & - & 228 & [27] \\
\hline
\end{tabular}

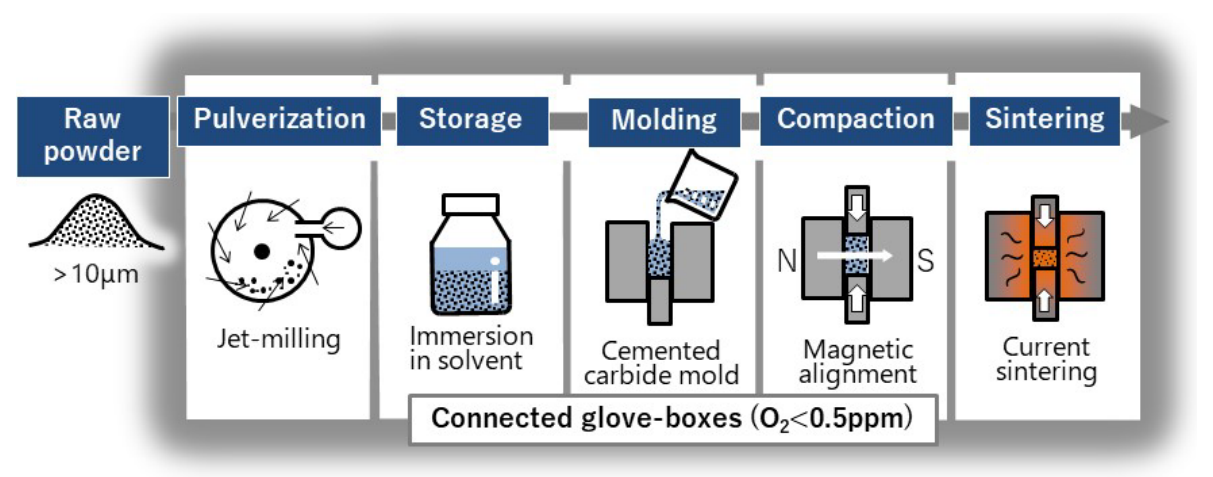

Fig. 3 Low oxygen powder metallurgy process for $\mathrm{Sm}_{2} \mathrm{Fe}_{17} \mathrm{~N}_{3}$ sintered magnets ${ }^{33)}$.

温成形法も試みられた21-27)。これらのうちいくつかの方法で は保磁力低下のない固化成形に成功しており，特に圧縮せん 断法では $\mathrm{Sm}_{2} \mathrm{Fe}_{17} \mathrm{~N}_{3}$ バルク磁石としては最高となる $228 \mathrm{~J} / \mathrm{m}^{3}$ の $(B H)_{\max }$ を達成した ${ }^{27}$ 。但し，これらの常温成形法は量産 性の低さや製品形状制約の問題から，実用技術として用いる のは難しい。

一方で，近年になって焼結による保磁力低下の原因は熱分 解ではなく, 粉末表面の酸化膜に起因することが見出された ${ }^{20}$. $\mathrm{Sm}_{2} \mathrm{Fe}_{17} \mathrm{~N}_{3}$ 粉末の表面酸化膜は通常は $\mathrm{Sm}_{2} \mathrm{O}_{3}$ と $\mathrm{Fe}_{2} \mathrm{O}_{3}$ から構 成され，加熱すると $\mathrm{Sm}_{2} \mathrm{Fe}_{17} \mathrm{~N}_{3}$ 母相との間に次のような酸化 還元反応が生じる：

$$
\mathrm{Sm}_{2} \mathrm{Fe}_{17} \mathrm{~N}_{3}+\mathrm{Fe}_{2} \mathrm{O}_{3} \rightarrow \mathrm{Sm}_{2} \mathrm{O}_{3}+19 \mathrm{Fe}+(3 \mathrm{~N})
$$

希土類元素である金属 $\mathrm{Sm}$ は還元力が非常に強いため, 数 $100^{\circ} \mathrm{C}$ の加熱でも上記の反応が進行する．また，反応式から も分かるように, $\mathrm{Fe}_{2} \mathrm{O}_{3}$ が僅かに還元されただけでも大量の
$\alpha-\mathrm{Fe}$ が析出する， $\alpha$ - Fe は軟磁性であるため，粒子表面に存 在すると逆磁区の発生サイトとなり, 結果的に保磁力低下に 繋がる.この仮説に従えば, 酸化膜のない粉末を焼結すれば, 保磁力低下のない $\mathrm{Sm}_{2} \mathrm{Fe}_{17} \mathrm{~N}_{3}$ 焼結磁石が実現できるはずであ る.ここで重要なことは, $\mathrm{Sm}_{2} \mathrm{Fe}_{17} \mathrm{~N}_{3}$ は希土類元素を含む上 に熱分解性であるために，水素還元熱処理による酸化膜除去 はできない。

そこで, 粉砕から焼結まで酸化膜を形成させずに燒結磁 石を作製できる低酸素粉末治金技術が試みられた ${ }^{28,29)}$ 。例え ば著者らの試みでは，Fig. 3 に示すような連結型グローブ ボックスを用いて微粉砕から焼結までの全工程を酸素濃度 $0.5 \mathrm{ppm}$ 以下の極低酸素雲囲気下で行われた ${ }^{29)}$. 本技術で得 られる 1 um 級の粉砕粉末の酸素濃度は, 従来の大気暴露さ れた市販粉末の $1 / 2 \sim 1 / 3$ 以下に抑制できる。この粉末を酸化 させることなく $500^{\circ} \mathrm{C}$ で加圧燒結すると, Fig. 4 に示すよう に粉末からの保磁力低下は $10 \%$ 程度である。つまり，表面 


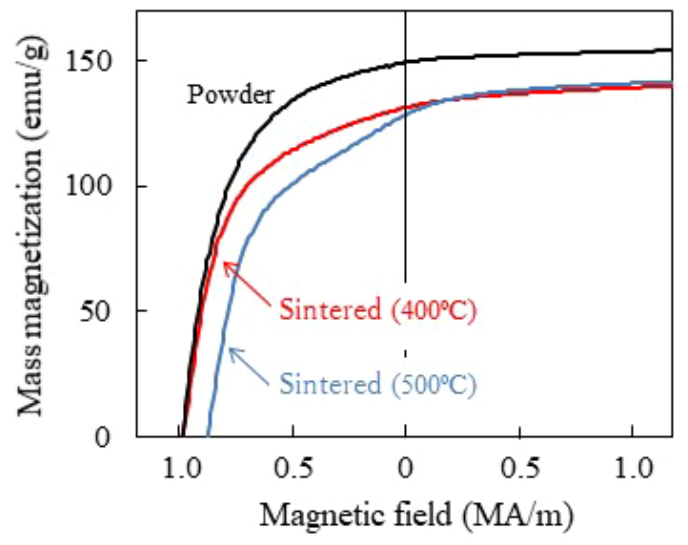

Fig. 4 Demagnetization curves of powder and sintered magnets produced by the low-oxygen powder metallurgy process ${ }^{29)}$.

酸化を抑制した粉末を焼結することにより，保磁力低下のな い $\mathrm{Sm}_{2} \mathrm{Fe}_{17} \mathrm{~N}_{3}$ 焼結磁石が実現できることが実証された。また, 焼結時の保磁力低下問題は類似組成である $(\mathrm{SmZr})(\mathrm{FeCo})_{10} \mathrm{~N}_{\mathrm{x}}$ にも起こることが予測されることから，低酸素粉末治金技術 はこの化合物にも有効と考えられる.

一方で, 最近の $\mathrm{Sm}_{2} \mathrm{Fe}_{17} \mathrm{~N}_{3}$ 焼結磁石の開発は, いくつかの 新たな課題も明らかにした，先述したように，これまでに多 くの低温成形方法が試みられたが，未だ高密度成形には至っ ていない. Table 1 にも示したように，焼結法により得られ た $\mathrm{Sm}_{2} \mathrm{Fe}_{17} \mathrm{~N}_{3}$ 磁石の相対密度は最大でも $91 \%$ に留まってい る. また, 表面酸化膜の抑制により大幅な保磁力低下は回避 できたものの, Fig. 4 に示すように焼結温度の上昇に伴う保 磁力低下は見られる。 これは緻密化に伴う粒子間の磁気結合 によるものと考えられるが, さらなる調查が必要である. 加 えて, 最も検討すべき課題は $\mathrm{Sm}_{2} \mathrm{Fe}_{17} \mathrm{~N}_{3}$ の保磁力の潜在力を 引き出すことである。低酸素粉末治金技術は保磁力低下を回 避できるものの, その保磁力は $1 \mathrm{MA} / \mathrm{m}$ であり, $20.7 \mathrm{MA} / \mathrm{m}$ の異方性磁界に比べるとはるかに低い. 従って, 保磁力の潜 在力を引き出すための開発が必要であり, 次節以下において その開発の現状について紹介する.

\section{2 保磁力向上のための焼結添加物の開発}

$\mathrm{Nd}_{2} \mathrm{Fe}_{14} \mathrm{~B}$ 磁石においては, 結晶粒界に特定の他元素を添 加すると保磁力が大きく改善することが知られており， $\mathrm{Sm}_{2} \mathrm{Fe}_{17} \mathrm{~N}_{3}$ においても同様な効果が得られる可能性がある. これまでにも, $\mathrm{Sm}_{2} \mathrm{Fe}_{17} \mathrm{~N}_{3}$ に対して様々な元素を添加して保 磁力を向上させる試みがされてきた，とりわけ，Zn 添加が 大幅に保磁力を向上することが多くの研究で示されており ${ }^{30)}$, 中でも Kuhrt らは Zn 添加によって $3.5 \mathrm{MA} / \mathrm{m}$ の巨大保磁力を 得ている ${ }^{31)}$. しかし, $\mathrm{Zn}$ 添加は $\mathrm{Sm}_{2} \mathrm{Fe}_{17} \mathrm{~N}_{3}$ 粒子の飽和磁化を 大幅に低下させるため, 結果的に $(B H)_{\text {max }}$ の改善には至って いない，従って，Znに代わる新たな添加元素を探索する必 要がある。これまでにも, Zn 以外の元素として In P Sn, Al $\mathrm{Ga}$ などが調べられてきたが, 保磁力向上に効果のある元素 は見つかっていない ${ }^{32}$. しかし, これまでの研究では, 熱分 解温度の制約のために調査は低融点金属を中心に行われてお
り，他の元素は殆ど調べられていない．保磁力を向上させる ためだけに添加剤の効果を調查する場合は, 融点の高い材 料に範囲を拡大する必要がある ${ }^{37,38)}$ ，また，これまでの研究 では表面酸化膜を持つ $\mathrm{Sm}_{2} \mathrm{Fe}_{17} \mathrm{~N}_{3}$ 粉末が使われていたことか ら, $\mathrm{Sm}_{2} \mathrm{Fe}_{17} \mathrm{~N}_{3}$ と添加元素の直接接触による正確な効果が調 べられたかは疑わしい，つまり，前述の低酸素粉末治金技術 を活用すれば，酸化膜のない粒子表面や粒界に直接元素を添 加できる. また，このアプローチは最小限の添加で最大の効 果を達成する可能性もある.

Matsuura らは, 磁性粉末の表面に金属膜を形成するために, プラズマ蒸着を利用した低酸素粉末被覆技術を開発した ${ }^{28)}$. 彼らは, この技術を用いて Zn ボンド磁石を作製し, 残留磁 気の低下を抑えながら保磁力の向上に成功しており, 結果的 に $200 \mathrm{~kJ} / \mathrm{m}^{3}$ の優れた $(B H)_{\text {max }}$ を持つ焼結磁石を作製した ${ }^{35)}$. Yamaguchi らも同様に, 金属膜を粉末表面に直接スパッタリ ングする技術を報告している ${ }^{36)}$.この技術は粉末を攪拌しな がらスパッタリングすることにより，粒子表面にナノオー ダーの被膜を均一に形成することができる。 また，スパッタ リング装置はグローブボックスと連結されているために, $\mathrm{Sm}_{2} \mathrm{Fe}_{17} \mathrm{~N}_{3}$ 粉末を大気暴露することはなく, 酸化膜を介さず に被覆処理が可能である. 実際に Fig. 5 の TEM写真からも 分かるように, $\mathrm{Sm}_{2} \mathrm{Fe}_{17} \mathrm{~N}_{3}$ 粒子に金属層が均一に被覆されて いる．また，XPS 表面分析により，酸化物がない単相の表面 被膜であることも実証されている。これまでにも，磁性粉末 に蒸着による金属成膜の技術は報告されているが33,37,38), 本 技術はこれらに比べ材料的制約が少なく，均一成膜が可能で ある。

Fig. 5 は20種類の非磁性金属元素を, 酸化膜のない $\mathrm{Sm}_{2} \mathrm{Fe}_{17} \mathrm{~N}_{3}$ 粉末表面に被覆し, 熱処理したときの保磁力変化 をまとめたものである ${ }^{39)}$. 現在のところ, $\mathrm{Al}$ や $\mathrm{Ti}, \mathrm{Mn}$ といっ た 9 元素が保磁力を向上させることが見出されている．興味 深いことに, これらの元素は, $\mathrm{Nd}_{2} \mathrm{Fe}_{14} \mathrm{~B}$ で有効とされる $\mathrm{Cu}$ や Dy, $\mathrm{Ga}$ などの元素と一致しておらず，この技術を用いた 更なる研究により, 保磁力向上に効果のある新たな元素や合 金が見つかることが期待される．また，本技術は $\mathrm{Sm}_{2} \mathrm{Fe}_{17} \mathrm{~N}_{3}$ 以外の希土類磁石の添加物を探索する手法としても有効と考 えられる。

\section{3 高保磁力希土類磁石のための粉末作製技術}

\section{1 化学的合成手法}

先述した通り，ネオジム磁石は高温に加熱を伴う液相焼結 が可能なため, 焼結磁石の保磁力は粉末から大幅に上昇す る. しかし, $\mathrm{Sm}_{2} \mathrm{Fe}_{17} \mathrm{~N}_{3}$ などの熱分解性化合物や準安定相化 合物などは液相焼結の適用が難しいため, Table 1 に示した ように, 焼結磁石の保磁力は原料粉末の保磁力に依存する.

従って, 高い保磁力を持つ原料粉末を準備することが重要と なる.

異方性焼結磁石を作製するためには，各粒子内の結晶方位 が一方向に揃っている, つまり単結晶粒子からなる粉末が必 要である. 従って, 異方性焼結磁石のための粉末は, 一般的 


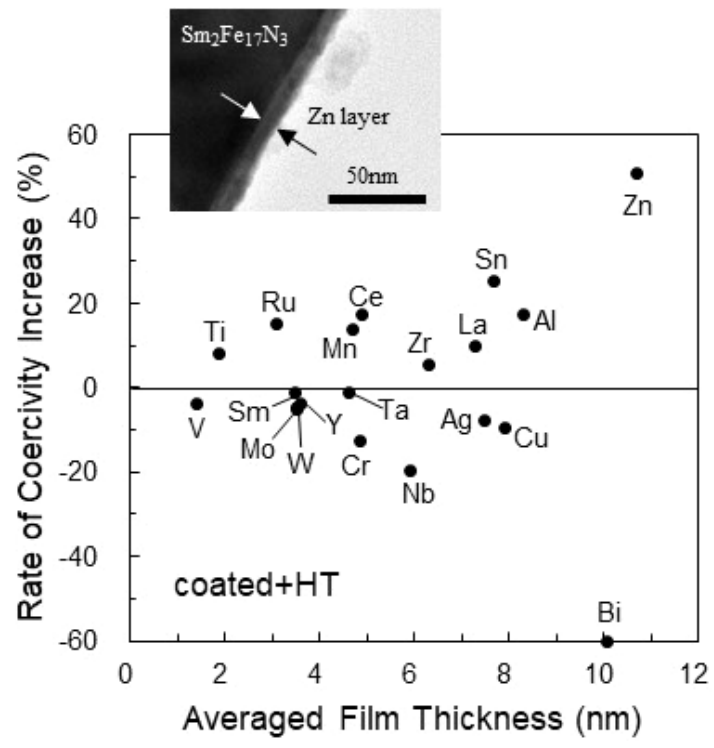

Fig. 5 Summary of the effects of coating 20 non-magnetic metals on the coercivity of $\mathrm{Sm}_{2} \mathrm{Fe}_{17} \mathrm{~N}_{3}$ powders ${ }^{36}$. All coated powders were heattreated at $500^{\circ} \mathrm{C}$. The inset shows a cross-sectional TEM image of a Zn-coated powder ${ }^{39}$.

には溶製法などで多結晶インゴットや粗粉末を準備し，これ を単結晶粉末となるまでボールミル法やジェットミル法など の機械的粉砕して原料粉末を得る. しかし, Fig. 6 に示すよ うに，粉砕法によって作製された $\mathrm{Sm}_{2} \mathrm{Fe}_{17} \mathrm{~N}_{3}$ 粉末の保磁力は 高くても $1 \mathrm{MA} / \mathrm{m}$ 程度であり, 現行の $\mathrm{Nd}_{2} \mathrm{Fe}_{14} \mathrm{~B}$ 磁石の保磁力 ( 2 MA/m) に比べて大きく劣る. 粉砕法による粉末は角部 を持つ多角形であることや表面損傷によって逆磁区が発生し やすく，保磁力が低くなると考えられる．

一方で，日悪化学工業は粗粉末を合成する方法であった 還元拡散法を改良し，粉砕なしで単結晶微粉末を作製する 直接還元拡散法を開発した ${ }^{11)}$. この方法は Fig. 7 に示すよう に湿式合成法などで準備した複合酸化物微粉末を $\mathrm{H}_{2}$ ガスお よび溶融 $\mathrm{Ca}$ を使って還元して希土類合金粉末を得る方法で ある. $\mathrm{Ca}$ 還元では副生成物として $\mathrm{CaO}$ が発生するため, 水 洗によって除去する工程を経る。また，アンモニア窒化は水 洗工程前に行われる。この方法により合成される単結晶粉末 は, 球形に近い形状を有し, かつ結晶性も高い特徵を有す る. Kumeらはこの方法よって約 $2 \mu \mathrm{m} の \mathrm{Sm}_{2} \mathrm{Fe}_{17} \mathrm{~N}_{3}$ 単結晶粉 末を合成し, 約 $1.5 \mathrm{MA} / \mathrm{m}$ の保磁力を得ることに成功してい

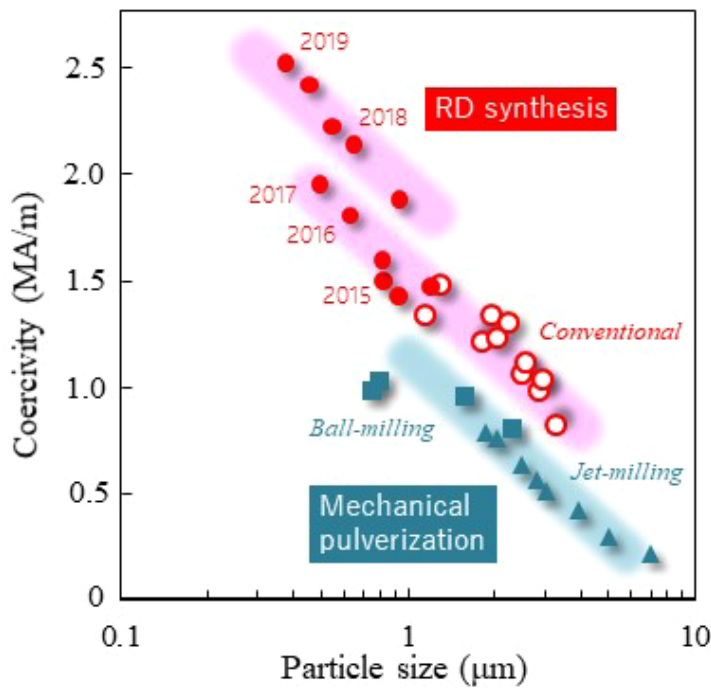

Fig. 6 Dependencies of coercivity on particle size for $\mathrm{Sm}_{2} \mathrm{Fe}_{17} \mathrm{~N}_{3}$ fine powders prepared by the mechanical pulverization and reduction diffusion methods ${ }^{11,41-43)}$.

る ${ }^{11)}$. しかし，この保磁力も異方性磁界の 7\% 程度であり， 更なる保磁力の向上が可能なはずである.

永久磁石の保磁力の依存性として最もよく知られるのは 粒径依存性であり, 保磁力は粒径の 2 乗の対数に反比例して 増加する ${ }^{40)}$. Fig. 6 の粉砕粉の結果を見ると, $\mathrm{Sm}_{2} \mathrm{Fe}_{17} \mathrm{~N}_{3}$ 粉末 に関しても明らかな粒径依存性を示すことが分かる。そこ で, Hirayamaらや Okada らは更なる粒径微細化ため, Ca 還 元拡散温度の低減を行った． Ca 還元拡散処理はこれまでは

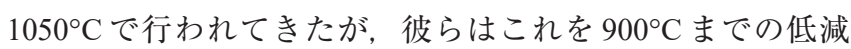
に成功した ${ }^{41,42)}$. これらの結果として, Fig. 8 に示すように粒 径をサブミクロンサイズまで微細化する技術を開発し, 保磁 力は粒径依存則に従って $1.85 \mathrm{MA} / \mathrm{m}$ まで向上できることを 示した. Fig. 8 に見られるように, 得られた粉末は等軸形状 かつ粒度分布が小さく，これらの特徴も高保磁力に貢献した と考えられる.

さらにOkada らは，Ca 還元拡散工程中に $\mathrm{Sm}_{2} \mathrm{Fe}_{17}$ 粉末の表 面に Sm-rich Sm-Fe 相が形成し，これが保磁力に悪影響を及 ぼしていることを見出した43).そこで，この異相形成を防ぐ 徐酸化工程を水洗工程の前に導入したところ, 保磁力の粒径 依存性の水準はさらに $0.4 \mathrm{MA} / \mathrm{m}$ 上昇した。さらに彼らは, $\mathrm{Sm}_{2} \mathrm{Fe}_{17} \mathrm{~N}_{3}$ 粉末の保磁力は最大で $2.55 \mathrm{MA} / \mathrm{m}$ まで発現するこ

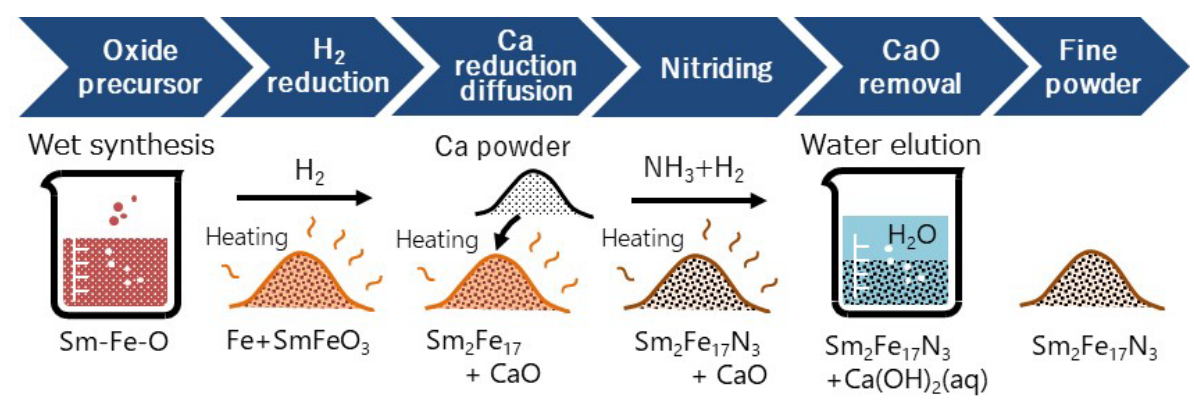

Fig. 7 Direct reduction diffusion process for synthesizing $\mathrm{Sm}_{2} \mathrm{Fe}_{17} \mathrm{~N}_{3}$ fine powder. 


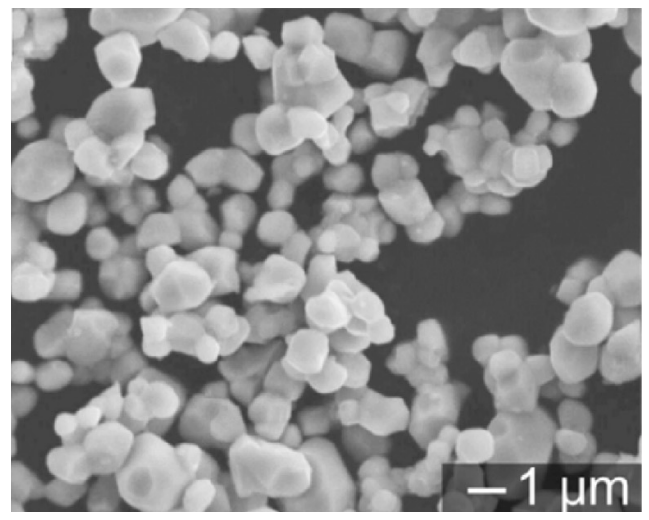

Fig. 8 Scanning electron microscopy (SEM) micrograph of $\mathrm{Sm}_{2} \mathrm{Fe}_{17} \mathrm{~N}_{3}$ fine powder synthesized by reduction diffusion process ${ }^{42)}$

とを実証しており ${ }^{44)}$ ，これは最新のネオジム磁石と比べても 高い值である ${ }^{45)}$. また，最近では $\mathrm{KCl}$ を還元凬である $\mathrm{Ca}$ の フラックスとして用い，かつ反応場に扔ける反応原子の密度 を減らすことで粒成長と粒子凝結を抑制し, $5.7 \mathrm{MA} / \mathrm{m}$ の巨 大保磁力を持つ $\mathrm{SmCo}_{5}$ 粉末の報告もある ${ }^{40)}$.

上記で概説したように，還元拡散法は年々発展し続けてお り, さらに大きな保磁力を持つ希土類磁石粉末の創製につな がることが期待される．ただし，現在の還元拡散法は水洗工 程を含むため, 粉末の表面酸化を回避することは困難であ る。従って, 還元拡散法による粉末を焼結磁石の原料粉末と して利用するためには，表面酸化を抑制する洗浄工程を開発 する必要がある.

3.2 物理的合成手法

前述の通り, 粒径微細化は磁石材料の保磁力向上に非常に 効果的である。また，粒径微細化は焼結を促進する効果もあ り，焼結緻密化の難しい $\mathrm{Sm}_{2} \mathrm{Fe}_{17} \mathrm{~N}_{3}$ や準安定系磁石に有効に 働くと期待される，従って，ナノサイズの希土類磁石粉末を 作製できれば，保磁力と緻密化の問題を同時に解決できる可 能性が高い．また，希土類磁石のナノ粉末は，究極の磁石を されるナノコンポジット磁石の原料粉末としての適用も期待 できる ${ }^{47}$.

希土類磁石のナノ粉末を作製する試みはいくつか報告され ている. Hadjipanayisらのグループは，表面活性剤を使った ボールミル粉砕を用いて $10 \mathrm{~nm}$ 以下の $\mathrm{SmCo}_{5}$ や $\mathrm{Nd}_{2} \mathrm{Fe}_{14} \mathrm{~B}$ の ナノ粉末を作製し，それぞれ $1.48 \mathrm{MA} / \mathrm{m}$ と $0.3 \mathrm{MA} / \mathrm{m}$ の保 磁力を得ている ${ }^{48,49)}$. また, 彼らは物理合成法であるクラス ター成膜法を用いて数 $\mathrm{nm}$ の Sm-Coナノ粉末の合成に成功し ているが, 非常に小さい保磁力しか得られていない ${ }^{50)}$.

最近, Hirayama らは熱プラズマ法による希土類磁石材料 のナノ粒子合成を試みている，熱プラズマ法では，Fig. 9 に 示すように, 高周波電力で励起させたプラズマは $10000 \mathrm{~K} に$ 達することから，原料粗粉末をプラズマ炎内に送り，蒸発 させる ${ }^{51,52)}$. 次に，下降気流によってプラズマ炎の外に出た 金属蒸気は核発生・凝集過程を経て最終的にナノ粒子とな る.ここで, プラズマ炎を出たナノ融滴は $10^{5} \mathrm{~K} / \mathrm{sec}$ の超急 冷下で凝固する。この冷却速度はメルトスピニングのそれ

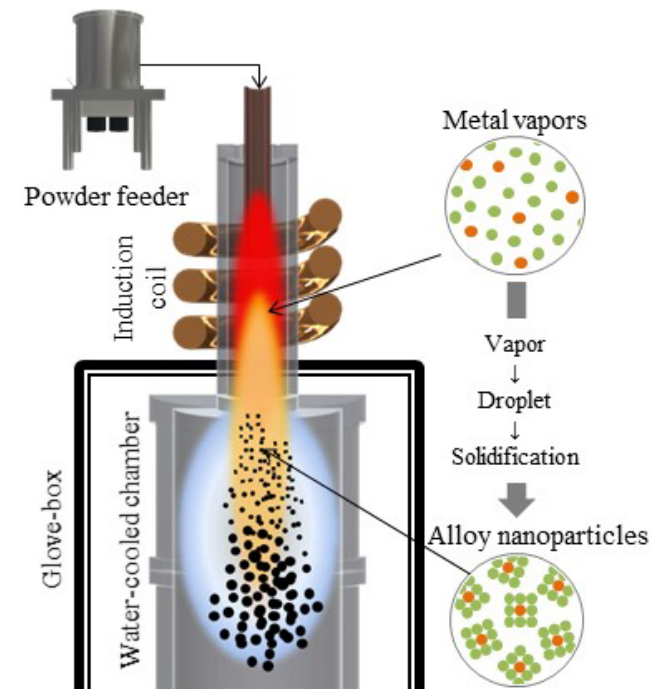

Fig. 9 Schematic of low-oxygen thermal plasma system for synthesizing rare-earth magnet powders ${ }^{54)}$.

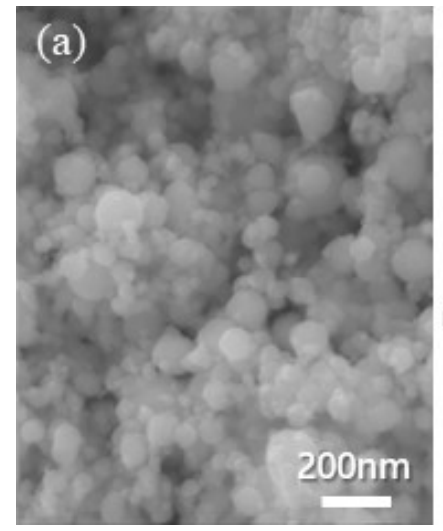

(b)

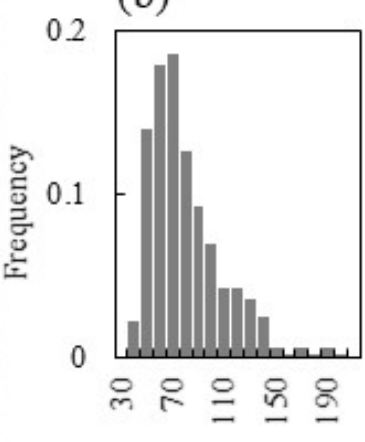

Particle size (nm)

Fig. 10 Sm-Co nanoparticles synthesized by low-oxygen thermal plasma system. (a) SEM image and (b) particle size distribution ${ }^{59)}$.

$\left(10^{4} \sim 10^{6} \mathrm{~K} / \mathrm{sec}\right)$ に近いため ${ }^{53}$ ，準安定相のナノ粒子形成も期 待できる。ここで，易酸化性である希土類合金のナノ粒子を 作製するには，わずかな酸素にも暴露させることなく合成打 よび回収することが肝要となる。 そこで，熱プラズマ装置の 一部をグローブボックスで覆い，極低酸素雾囲気とするこ とで, 易酸化金属のナノ粒子の酸化膜形成を防ぐこと可能 であることも実証されている ${ }^{54)}$. Fig. 10 は熱プラズマ法で合 成した希土類磁石ナノ粒子の一例であり, 平均粒径 $70 \mathrm{~nm} の$ Sm-Co 合金ナノ粒子である。この他にも，Y-Fe や Nd-Fe, $\mathrm{Sm}-\mathrm{Fe}$ 合金のナノ粒子合成に成功している．特に, Sm-Feに おいては $\mathrm{TbCu}_{7}$ 型合金の単結晶ナノ粒子の合成にも確認して おり，これまで困難であった準安定相合金の単結晶粉末の作 製も期待できる ${ }^{55}$.

\section{4 結 言}

$\mathrm{Nd}_{2} \mathrm{Fe}_{14} \mathrm{~B}$ 磁石の代替として, $\mathrm{Sm}_{2} \mathrm{Fe}_{17} \mathrm{~N}_{3}$ や $\mathrm{TbCu}_{7}$ 型化合物 などの準安定材料が注目されているが，これらの材料の実用 的な磁石を実現するためには, 焼結の難しさや低保磁力など 
のプロセス上の問題を克服する必要がある。これらの問題を 克服するために，様々な粉末作製および粉末治金の手法が 試みられてきた. $\mathrm{Sm}_{2} \mathrm{Fe}_{17} \mathrm{~N}_{3}$ の焼結磁石開発は長きに渡り熱 分解と保磁力低下に妨げられてきたが, 最近なって保磁力低 下を克服するための低酸素粉末治金アプローチが発見され， $\mathrm{Sm}_{2} \mathrm{Fe}_{17} \mathrm{~N}_{3}$ 焼結磁石の実現可能性が開かれた。但し，高性能 磁石の達成に向けては, 高保磁力の原料粉末も必要である. そのため, 新たな微粉末作製技術として還元拡散や熱プラズ マプロセスなどの化学的および物理的合成法が開発されてお り, その結果は従来の機械的粉砕手法を上回っている. 特に, 還元拡散プロセスでは, $2.5 \mathrm{MA} / \mathrm{m}$ という巨大保磁力を示す $\mathrm{Sm}_{2} \mathrm{Fe}_{17} \mathrm{~N}_{3}$ 微粉末を作製できるに至っている.

このように，新しい粉末プロセスの開発により，これま で困難であった高保磁力 $\mathrm{Sm}_{2} \mathrm{Fe}_{17} \mathrm{~N}_{3}$ 粉末とバルク磁石が作製 されている.さらに，これらの新しいプロセスは，準安定 $\mathrm{TbCu}_{7}$ 型磁石への適用も期待できる。一方で, 焼結緻密化が 不十分であるなどの問題は未だ解決されていないが，新たな 粉末プロセスへの挑戦により, 高性能希土類永久磁石への新 たな道が開かれることが期待できる。

\section{文献}

1) Y. Seo, S. Morimoto: Resour. Policy, 39 (2014) 15-20.

2) Y. Watanabe: Shigen Chishitsu, 60 (2010) 103-122. (in Japanese).

3) T. Iriyama, K. Kobayashi, N. Imaoka, T. Fukuda, H. Kato, Y. Nakagawa: IEEE Trans. Magn., 28 (1992) 2326-2331.

4) J. M. D. Coey, H. Sun: J. Magn. Magn. Mater., 87 (1990) 251254.

5) S. Sakurada, A. Tsutai, T. Hirai, Y. Yanagida, M. Sahashi, S. Abe, T. Kaneko: J. Appl. Phys., 79 (1996) 4611-4613.

6) K. Ohashi, Y. Tawara, R. Osugi, M. Shimao: J. App. Phys., 64 (1988) 5714-5716.

7) Y. Hirayama, Y. K. Takahashi, S. Hirosawa, K. Hono: Scripta Mater., 138 (2017) 62-65.

8) Y. Hirayama, Y. K. Takahashi, S. Hirosawa, K. Hono: Scripta Mater., 95 (2015) 70-72.

9) K. Schnitzke, L. Schultz, J. Wecker, M. Katter: Appl. Phys. Lett., 57 (1990) 2853-2855.

10) K. Takagi, H. Nakayama, K. Ozaki, K. Kobayashi: J. Magn. Magn. Mater., 324 (2012) 1337-1341.

11) M. Kime, T. Tomimoto, S. Yamamoto, K. Ihara, H. Yoshihara, S. Tada, M. Sumitomo: J. Jpn Inst. Met. Mater., 76 (2012) 107-111 (in Japanese).

12) M. Katter, J. Wecker, L. Schultz: Appl. Phys., 70 (1991) 3188-3196.

13) W. Liu, Q. Wang, X. K. Sun, X. G. Zhao, T. Zhao, Z. D. Zhang, Y. C. Chuang: J. Magn. Magn. Mater., 131 (1994) 413-416.

14) K. Takagi, M. Jinno, K. Ozaki: J. Magn. Magn. Mater., 454 (2018) 170-175.

15) E. W. Singleton, J. Strzeszewski G. C. Hadjipanayis, D. J. Sellmyer: J. Appl. Phys., 64 (1988) 5717.
16) I. Dirba, H. Sepehri-Amin, T. Ohkubo, K. Hono: Acta Mater., 165 (2019) 373-380.

17) K. Machida, Y. Nakatani, G. Adachi: Appl. Phys. Lett., 62 (1993) 2874-2876.

18) S. Ito, M. Kikuchi, T. Fujii, T. Ishikawa: J. Magn. Magn. Mater., 280 (2004) 15-21.

19) D. T. Zhang, M. Yue, J. X. Zhang: Powder Metal., 50 (2007) 215-218

20) K. Takagi, H. Nakayama, K. Ozaki: J. Magn. Magn. Mater., 324 (2012) 2336-2341.

21) B.-P. Hu, X.-L. Rao, J.-M. Xu, G.-C. Liu, Y.-Z. Wang, X.-L. Dong, D.-X. Zhang, M. Cai: J. Appl. Phys., 74 (1993) 489494.

22) H. Oda, K. Kondo, H. Uchida, Y. Matsumura, S. Tachibana, T. Kawanabe: Jpn. J. Appl. Phys., 34 (1995) L35-37.

23) T. Mashimo, X. Huang, S. Hirosawa, K. Makita, Y. Kato, S. Mitsudo, M. Motokawa, J. Magn. Magn. Mater., 210 (2000) 109-120.

24) A. Chiba, K. Ooyabu, Y. Morizono, T. Maeda, S. Sugimoto, T. Kozuka, E. Kakimoto, K. Kawahara, T. Watanabe: Mater. Sci. Forum, 449-452 (2004) 1037-1040.

25) T. Maki, S. Sugimoto, T. Kagotani, K. Inomata, J. Akedo: Mater. Trans., 45 (2004) 369-372.

26) T. Saito, M. Fukui, H. Takeishi: Scripta Mater., 53 (2005) $1117-1121$.

27) T. Saito, H. Kitazima: J. Magn. Magn. Mater., 323 (2011) 2154-2157.

28) M. Matsuura, Y. Nishijima, N. Tezuka, S. Sugimoto, T. Shoji, N. Sakuma: J. Magn. Magn. Mater., 467 (2018) 64-48.

29) K. Takagi, R. Soda, M. Jinno, W. Yamaguchi: J. Magn. Magn. Mater., 506 (2020) 166811.

30) Y. Otani, A. Moukarika, H. Sun, J. M. D. Coey, E. Devlin, I. R. Harris: J. Appl. Phys., 69 (1991) 6735-6737.

31) C. Kuhrt, H. Cerva, L. Shultz: Appl. Phys. Lett., 64 (1994) 797-799.

32) K. Machida, K. Noguchi, M. Nishimura, G. Adachi: J. appl. Phys., 87 (2000) 5317-5319.

33) N. Imaoka, Y. Koyama, T. Nakao, S. Nakaoka, T. Yamaguchi, E. Kakimoto, M. Tada, T. Nakagawa, M. Abe: J. Appl. Phys., 103 (2008) 07E129.

34) T. Saito, T. Deguchi, H. Yamamoto: AIP Adv., 7 (2017) 056204.

35) R. Matsunami, M. Matsuura, N. Tezuka, S. Sugimoto: J. Magn. Soc. Jpn., 44 (2020) 64-69.

36) W. Yamaguchi, R. Soda, K. Takagi: J. Magn. Magn. Mater., 498 (2020) 166101.

37) K. Makita, S. Hirosawa: J. Alloys Compd., 260 (1997) 236241

38) H. Fukunaga, T. Aikawa, S. Nagaoka, Y. Kanai: J. Magn. Magn. Mater., 157 (1996) 105-106. 
39) W. Yamaguchi, K. Takagi: J. Magn. Magn. Mater., 516 (2020) 167327.

40) R. Ramesh, G. Thomas, M. Ma: J, Appl. Phys., 64 (1988) 6416-6423.

41) Y. Hirayama, A. K. Panda, T. Okubo, K. Hono: Scripta Mater., 120 (2016) 27-30.

42) S. Okada, K. Suzuki, E. Node, K. Takagi, K. Ozaki, Y. Enokido: J. Alloy Compd., 695 (2017) 1617-1623.

43) S. Okada, E. Node, K. Takagi, Y. Fujiwara, Y. Enokido: J. Alloy Compd., 804 (2019) 237-242.

44) Press release of National Institute of Advanced Industrial Science and Technology: https://www.aist.go.jp/aist_j/press_release/ pr2019/pr20191021/pr20191021.html

45) H. Sepehri-Amin, L. Liu, T. Okubo, M. Yano, T. Shojji, A. Kato, T. Schrefl, K. Hono: Acta Mater., 99 (2015) 297-306.

46) Y. Dong, T. Zhang, Z. Xia, H. Wang, Z. Ma, X. Liu, W. Xia, J. M. D. Coey: 11 (2019) 16962.

47) B. Balamurugan, D. J. Sellmyer, G. C. Hadjipanayis, R. Skomski: Scripta Mater., 67 (2012) 542-547.

48) N. G. Akdogan, G. C. Hadjipanayis, D. J. Sellmyer: J. Appl. Phys., 105 (2009) 07A710.

49) N. G. Akdogan, G. C. Hadjipanayis, D. J. Sellmyer: Nanotechnology, 21 (2010) 1-5.
50) S. Stoyanov, V. Skumryev, Y. Zhang, Y. Huang, G. Hadjipanayis, J. Nogues: J. Appl. Phys., 93 (2003) 7592-7594.

51) M. Kambara, A. Kitayama, K. Homma, T. Hideshima, M. Kaga, K.-Y. Sheem, S. Ishida, T. Yoshida: J. Appl. Phys., 115 (2014) 143302.

52) A. Pant, T. Seth, V. B. Raut, V. P. Gajbhiye, S. P. Newale, A. K. Nandi, H. Prasanth, R. K. Pandey: Cent. Eur. J. Energ. Mater., 13 (2016) 53e71.

53) V. I. Tkatch, A. I. Limanovskii, S. N. Denisenko, S. G. Rassolov: Mater. Sci. Eng. A, 323 (2002) 91-96.

54) Y. Hirayama, K. Suzuki, W. Yamaguchi, K. Takagi: J. Alloy Compd., 768 (2018) 608-612.

55) Y. Hirayama, M. Sigeta, Z. Liu, N. Yodoshi, A. Hosokawa, K. Takagi: J. Alloy Compd., (2021) (in press)

56) Y. Hirayama, T. Miyake, K. Hono: JOM, 67 (2015) $1344-$ 1349.

57) Web site of Hitach Metals Ltd.: http://www.hitachi-metals. co.jp/products/auto/el/pdf/nmx.pdf

58) H. Yamamoto, et al., Technical Report: Properties, stability and applications of high-performance permanent magnets. Tokyo: The Institute of Electrical Engineers of Japan, 1999. Japanese.

59) K. Takagi: KINZOKU, 90 (2020) 889-897. (in Japanese) 